\title{
ANTI-HYPERGLYCEMIC, ANTIOXIDANT, AND ANTI-INFLAMMATORY ACTIVITIES OF EXTRACTS AND METABOLITES FROM Sida acuta AND Sida rhombifolia
}

\author{
Amira Arciniegas, Ana L. Pérez-Castorena*, Antonio Nieto-Camacho, Yuko Kita and Alfonso Romo de Vivar \\ Instituto de Química, Universidad Nacional Autónoma de México, Circuito Exterior, Ciudad Universitaria, Coyoacán 04510, \\ Ciudad de México, México.
}

Recebido em 09/06/2016; aceito em 22/09/2016; publicado na web em 26/10/2016

\begin{abstract}
Species of genus Sida are used around the world for a large amount of therapeutic treatments, including hyperglycemia. $\alpha$-Glucosidase inhibitors are recognized as valuable tools for reducing postprandial hyperglycemia by retarding absorption of glucose. The effect of extracts and isolated compounds of $S$. acuta and S. rhombifolia on inhibition of $\alpha$-glucosidase as primary screening of antihyperglycemic activity was tested using yeast and mammalian $\alpha$-glucosidases. When yeast $\alpha$-glucosidase was used the acetone extracts of $S$. acuta and $S$. rhombifolia showed $\mathrm{IC}_{50}$ values of $8.49 \pm 0.66$ and $8.10 \pm 0.34 \mu \mathrm{gL}^{-1}$, respectively, and the most active compound was $p$-hydroxyphenethyl trans-ferulate $\left(\mathrm{IC}_{50} 19.24 \pm 1.73 \mu \mathrm{mol} \mathrm{\textrm {L } ^ { - 1 }}\right)$ followed by $\beta$-sitosteryl glucopyranoside $\left(\mathrm{IC}_{50} 32.70 \pm 1.35 \mu \mathrm{mol} \mathrm{L} \mathrm{L}^{-1}\right.$ ). However, the activity of extracts and isolated compounds decreased significantly when mammalian $\alpha$-glucosidase was used, indicating that substrates affinity is higher for type 1 enzymes. The antioxidant and anti-inflammatory activities of extracts and isolates were also tested since many diabetic complications are associated to the oxidative stress and inflammatory immune responses. Acetone extracts were the most active in all evaluations. $p$-Hydroxyphenethyl trans-ferulate, could be associated to these activities, since it was active in the three evaluations. This effect could be related to its phenolic character.
\end{abstract}

Keywords: $\alpha$-glucosidase; DPPH; TPA; Sida acuta; Sida rhombifolia.

\section{INTRODUCTION}

The genus Sida (Malvaceae) groups around 200 species spread worldwide in tropical and warm regions, 35 of which occur in Mexico, included S. acuta and S. rhombifolia. ${ }^{1}$ Species of this genus have a large amount of therapeutic uses; in Africa they are used to treat malaria, gastrointestinal infections, varicella, variola, and hepatitis $\mathrm{B} ;{ }^{2,3}$ in Asia they serve as tonic, antipyretic, and to cure disorders of the nervous system, hyperglycemia, and liver and blood problems; $;, 5$ and in Central America they are taken as medication for fever, asthma, renal inflammation, ulcers, and worm infections. ${ }^{6}$ Their use as antituberculosis, hypotensive and cytotoxic agents, and in urinary and cardiac diseases is also common. ${ }^{7}$ In Mexico $S$. acuta is used to treat fever, and stomach and teeth ache and S. rhombifolia is employed as disinfectant and to cure diarrhea, ulcers and tumours. ${ }^{8}$ As a result of the abundant activities of these plants there are also many pharmacological evaluations; their analgesic, ${ }^{9}$ antidiarreic, ${ }^{10}$ anti-oxidant, vasorelaxant, ${ }^{11}$ and anti-hyperglycemic activities, ${ }^{12}$ among others, have been tested, mainly from extracts of different species. ${ }^{7}$ Previous chemical reports show the presence of ecdysteroids, ${ }^{13,14}$ alkaloids, ${ }^{11,15}$ and flavonoids, ${ }^{11,16}$ as main secondary metabolites in S. acuta and S. rhombifolia.

Diabetes mellitus (DM), a chronic metabolic disease characterized by high level of glycemia, is becoming a serious problem around the world. There are two major types of DM, type- 1 is insulin dependent and arises from defects in the insulin gene causing an inefficient or no insulin production by the pancreas, and type- 2 is a noninsulin dependent disease characterized by the reduction of insulin secretion and resistance to the metabolic effects of insulin play role. Worldwide, in 2013 there were about 380 million and for 2035 is expected to be 592 million diabetic patients. Among them, $90 \%$ are DM type- 2 cases. ${ }^{17} \alpha$-Glucosidase inhibitors are one of the six groups of drugs in the prescription of DM. They act by decreasing the postprandial

*e-mail: alperezc@unam.mx hyperglycemia through the inhibition of the carbohydrate-hydrolysing enzymes, delaying the release of glucose from the oligosaccharides. ${ }^{18}$ Additionally, many diabetic complications are associated to oxidative stress and inflammatory immune responses. Free radicals and elevated circulating inflammatory markers can predict the development of diabetes mellitus. Thus, several drugs with anti-inflammatory properties lower glycemia and possibly decrease the risk of developing type 2 diabetes, and in the same way, the presence of antioxidant sources have potential benefits in obesity related diseases as DM. ${ }^{19}$ On the bases of the utilization in popular medicine of the plants of the genus Sida related above, and since there are no chemical reports on mexican $S$. acuta and $S$. rhombifolia, this paper describes their chemical composition, the effect as $\alpha$-glucosidase inhibitors, and the antioxidant and anti-inflammatory activities of extracts and isolates of these Sida species.

\section{EXPERIMENTAL}

\section{General}

Melting points were determined using a Fisher Jones melting point apparatus and are uncorrected. IR spectra were recorded on a Nicolet Magna-IR 750 spectrometer. 1D and 2D NMR spectra were obtained on a Bruker Avance III $400 \mathrm{MHz}$ or on a Varian-Unity Inova $500 \mathrm{MHz}$ spectrometer with tetramethylsilane (TMS) as internal standard. For Direct Analysis in Real Time Mass Spectroscopy (DARTMS) a JEOL AccuTOF JMS-T100LC DART mass spectrometer was used. ESIMS were performed on an ESI ion trap Bruker Esquire 6000 mass spectrometer. FABMS were obtained on a JEOL JMS-SX102A mass spectrometer operated with an acceleration voltage of $10 \mathrm{kV}$, and samples were desorbed from a nitrobenzyl alcohol matrix using $6 \mathrm{kV}$ xenon atoms. All MS analyses were performed at low resolution. Vacuum column chromatography (VCC) was performed using Silica gel 60 G (Merck, Darmstadt, Germany). Flash column chromatography (FCC) was run using Silica gel 60 
(230-400 Macherey-Nagel). TLC was carried out on Silica gel 60 $\mathrm{GF}_{254}$ and preparative TLC on Silica gel $\mathrm{GF}_{254}$ (Macherey-Nagel), layer thickness $2.0 \mathrm{~mm}$.

\section{Plant Material}

S. acuta Bum. f. and S. rhombifolia $\mathrm{L}$. were collected at the archeological zone La Joya, Medellin de Bravo district, Veracruz, México, in March 2012. Voucher specimens were deposited at the Herbarium del Instituto de Biología, UNAM, México (MEXU 1319742 for S. acuta and MEXU 1241720 for S. rhombifolia).

\section{Extraction and isolation}

Dried and ground aerial parts ( $970 \mathrm{~g}$ ) of $S$. acuta were successively extracted with hexane, acetone and methanol, $5 \mathrm{~L}$ of each. Solvents were removed at reduced pressure to obtain the corresponding extracts. The hexane extract (5.6 g) was subjected to VCC eluting with hexaneEtOAc mixtures of increasing polarity to obtain 60 fractions of $75 \mathrm{~mL}$. Fractions eluted with hexane-EtOAc 19:1 afforded $180 \mathrm{mg}$ of a mixture $\beta$-sitosterol (1)-stigmasterol (2). The acetone extract ( $10 \mathrm{~g})$ was purified by VCC eluted with hexane-acetone gradient mixtures to collect 150 fractions of $150 \mathrm{~mL}$. Fractions eluted with hexane-acetone 19:1 produced the mixture 1-2 $(28 \mathrm{mg})$. Purification of its mother liquors (620 $\mathrm{mg}$ ) by FCC eluted with hexane-acetone 9:1 (30 fractions of $15 \mathrm{~mL}$ ) led to the isolation of $13^{2}$-hydroxyphaeophytin a $(3,17 \mathrm{mg})$. Fractions obtained with hexane-acetone $4: 1$ produced $\beta$-sitosteryl glucopyranoside $(4,80 \mathrm{mg})$. Fraction eluted with hexane-acetone 7:3 were treated with charcoal/acetone and the resulting mixture $(220 \mathrm{mg})$ was purified by FCC eluted with hexane-acetone 1:1 (45 fractions of $10 \mathrm{~mL}$ ) to obtain $35 \mathrm{mg}$ of a mixture which by preparative TLC (hexane-acetone 1:1) afforded $p$-hydroxyphenethyl trans-ferulate $(\mathbf{5}, 6 \mathrm{mg})$. The methanol extract (74 g) was fractionated through a VCC using EtOAc-MeOH gradient system to obtain 95 fractions of $500 \mathrm{~mL}$ which by TLC analysis were grouped in: fraction A obtained with EtOAc, fraction B obtained with EtOAc-MeOH 9:1, and fraction C obtained with EtOAc-MeOH 4:1. Fraction A (3.5 g) was treated with charcoal/acetone and purified by VCC using EtOAc-MeOH gradient system as eluent to collect 50 fractions of $50 \mathrm{~mL}$ which were grouped by TLC analysis in fractions A1 and A2 eluted with EtOAc and EtOAc-MeOH 49:1, respectively. Fraction A1 $(850 \mathrm{mg})$ was submitted to a FCC eluted with EtOAc$\mathrm{MeOH}$ 19:1 (30 fractions of $20 \mathrm{~mL}$ ) to afford 20-hydroxyecdisone (6, $46 \mathrm{mg}$ ) and a mixture $(340 \mathrm{mg}$ ) which was purified by FCC eluted with hexane-acetone 1:1 (20 fractions of $10 \mathrm{~mL}$ ) followed by preparative TLC (hexane-acetone 1:1) to obtain $5 \mathrm{mg}$ of $\mathbf{5}$. Fraction A2 (450 mg) purified by FCC eluted with EtOAc-MeOH 9:1 (30 fractions of $15 \mathrm{~mL}$ ) yielded a mixture $(45 \mathrm{mg})$ which by preparative RPTLC $\left(\mathrm{H}_{2} \mathrm{O}-\mathrm{MeOH}\right.$ 1:1) led to the isolation of 20-hydroxy-24-hydroxymethylecdysone (7, $10 \mathrm{mg})$. From fraction $B$ only $\beta$-sitosteryl glucopyranoside $(4,110 \mathrm{mg})$ was isolated. Fraction $\mathrm{C}(4.8 \mathrm{~g})$ was subjected to $\mathrm{VCC}\left(\mathrm{CH}_{2} \mathrm{Cl}_{2}-\mathrm{MeOH}\right.$ gradient system) to obtain fraction $\mathrm{C} 1$, from fractions eluted with $\mathrm{CH}_{2} \mathrm{Cl}_{2}-\mathrm{MeOH} 4: 1$. Fraction $\mathrm{C} 1(859 \mathrm{mg})$ was purified by Sephadex LH 20 column eluted with $\mathrm{MeOH}$ ( 25 fractions of $30 \mathrm{~mL}$ ) to obtain uridine $(\mathbf{1 0}, 42 \mathrm{mg})$. Dried and ground aerial parts $(1.8 \mathrm{Kg})$ of $S$. rhombifolia were worked out as described for $S$. acuta. The hexane extract $(10 \mathrm{~g})$ produced only a mixture of $\beta$-sitosterol-stigmasterol $(\mathbf{1 - 2}, 280 \mathrm{mg})$. The acetone extract $(13 \mathrm{~g})$ was purified by VCC eluted with hexane-acetone gradient mixtures to obtain 125 fractions of 150 $\mathrm{mL}$. Fractions eluted with hexane-acetone 9:1 produced $\mathbf{1}$ and $\mathbf{2}$ as a mixture $(48 \mathrm{mg})$. Fractions eluted with hexane-acetone 1:1 were treated with charcoal/acetone to obtain a mixture $(440 \mathrm{mg})$ which by FCC eluted with hexane-acetone 2:3 (30 fractions of $15 \mathrm{~mL}$ ) produced 20-hydroxyecdysone 20,22-monoacetonide $(\mathbf{9}, 40 \mathrm{mg}$ ) and $5 \mathrm{mg}$ of
5. The methanol extract ( $105 \mathrm{~g})$ was fractionated thought VCC using EtOAc-MeOH gradient system as eluent to collect 95 fractions of 500 $\mathrm{mL}$. Fractions eluted with EtOAc were treated with charcoal/acetone to obtain a mixture $(3.4 \mathrm{~g})$ which was purified by VCC eluted with hexane-acetone gradient system (60 fractions of $50 \mathrm{~mL}$ ) to obtain $\beta$-sitosteryl glucopyranoside $(150 \mathrm{mg})$ and fraction D. Fraction D (1.1 g) was purified by FCC eluted with hexane-acetone 1:1 (50 fractions of $50 \mathrm{~mL})$ to afford a mixture $(200 \mathrm{mg})$ which was rechromatographed on a FCC eluted with $\mathrm{CH}_{2} \mathrm{Cl}_{2}$-acetone 4:1 (20 fractions of $100 \mathrm{~mL}$ ) to obtain 5 (8 mg). Fractions eluted with EtOAc-MeOH 19:1 (10 g) were purified by VCC (hexane-acetone gradient system) to obtain 84 fractions of $200 \mathrm{ml}$ which were analyzed by TLC and grouped in: fraction E eluted with hexane-acetone 3:2, fraction $\mathrm{F}$ with hexane-acetone $1: 1$, fraction $\mathrm{G}$ with hexane-acetone $2: 3$, and fraction $\mathrm{H}$ with acetone. Fraction E produced $200 \mathrm{mg}$ of $\beta$-sitosteryl glucopyranoside, and from fraction F $240 \mathrm{mg}$ of $\mathbf{6}$ were isolated. Fraction $\mathrm{G}$ (649 mg) was purified by $\mathrm{FCC}\left(\mathrm{CH}_{2} \mathrm{Cl}_{2}-\mathrm{MeOH} 9: 1\right)$ to obtain 35 fractions of $25 \mathrm{~mL}$ which were grouped by TLC analysis in fractions $\mathrm{G} 1$ and G2. Fraction G1 $(95 \mathrm{mg})$ was purified by $\mathrm{FCC}\left(\mathrm{CH}_{2} \mathrm{Cl}_{2}-\mathrm{MeOH} 85: 15\right)$ to obtain 25 fractions of $5 \mathrm{~mL}$ and led to the isolation of $6(55 \mathrm{mg})$. Fraction $\mathrm{G} 2(75 \mathrm{mg})$ was purified by preparative RPTLC $\left(\mathrm{H}_{2} \mathrm{O}-\mathrm{MeOH} 1: 1\right)$ to obtain $7(10 \mathrm{mg})$. Fraction $\mathrm{H}(2.5 \mathrm{~g})$ was purified by $\mathrm{VCC}\left(\mathrm{CH}_{2} \mathrm{Cl}_{2}{ }^{-}\right.$ $\mathrm{MeOH}$ gradient system) to obtain 70 fractions of $50 \mathrm{~mL}$ which were grouped by TLC analysis in: fraction $\mathrm{H} 1$ eluted with $\mathrm{CH}_{2} \mathrm{Cl}_{2}-\mathrm{MeOH}$ 9:1, fraction $\mathrm{H} 2$ obtained with $\mathrm{CH}_{2} \mathrm{Cl}_{2}-\mathrm{MeOH} 4: 1$ and fraction $\mathrm{H} 3$ collected with $\mathrm{CH}_{2} \mathrm{Cl}_{2}-\mathrm{MeOH} 7: 3$. Fraction $\mathrm{H} 1(80 \mathrm{mg})$ was purified by FCC elued with AcOEt-MeOH 85:15 (25 fractions of $5 \mathrm{~mL}$ ) to obtain $28 \mathrm{mg}$ of inosine $(\mathbf{8})$. Fraction $\mathrm{H} 2(215 \mathrm{mg})$ was purified by a preparative TLC $\left(\mathrm{CH}_{2} \mathrm{Cl}_{2}-\mathrm{MeOH} 7: 3\right)$ followed of a preparative RPTLC $\left(\mathrm{H}_{2} \mathrm{O}-\mathrm{MeOH}\right.$ 3:2) to obtain 25-acetoxy-20-hydroxyecdysone 3-O- $\beta$-Dglucopyranoside $(\mathbf{1 1}, 20 \mathrm{mg})$. Fraction $\mathrm{H} 3(503 \mathrm{mg})$ were submitted to a Sephadex LH 20 column eluted with $\mathrm{H}_{2} \mathrm{O}-\mathrm{MeOH}$ 9:1 (20 fractions of $20 \mathrm{~mL}$ ) to obtain glycerol $(30 \mathrm{mg})$.

p-Hydroxyphenethyl trans-ferulate (5): colorless needles; mp 164-167 ${ }^{\circ} \mathrm{C}$; IR (KBr) $v_{\max } / \mathrm{cm}^{-1}: 3475,1676 ;{ }^{1} \mathrm{H} \mathrm{NMR}\left(\mathrm{CD}_{3} \mathrm{OD}\right.$, $500 \mathrm{MHz})$ and ${ }^{13} \mathrm{C} \mathrm{NMR}\left(\mathrm{CD}_{3} \mathrm{OD}, 125 \mathrm{MHz}\right)$ see supporting material; DARTMS $m / z, 314[\mathrm{M}]^{+}$.

20-Hydroxyecdysone (6): White amorphous powder; IR (KBr) $v_{\max } / \mathrm{cm}^{-1}: 3347,1645 ;{ }^{1} \mathrm{H}$ NMR $\left(\mathrm{CD}_{3} \mathrm{OD}, 400 \mathrm{MHz}\right)$ and ${ }^{13} \mathrm{C} \mathrm{NMR}$ $\left(\mathrm{CD}_{3} \mathrm{OD}, 100 \mathrm{MHz}\right)$ see supporting material. DARTMS $\mathrm{m} / \mathrm{z} 481$ $[\mathrm{M}+\mathrm{H}]^{+}$.

20-Hydroxy-24-hydroxymethylecdysone (7): White amorphous powder; IR (KBr) $v_{\max } / \mathrm{cm}^{-1}: 3390,1659 ;{ }^{1} \mathrm{H}$ NMR $\left(\mathrm{CD}_{3} \mathrm{OD}\right.$, $500 \mathrm{MHz})$ and ${ }^{13} \mathrm{C} \mathrm{NMR}\left(\mathrm{CD}_{3} \mathrm{OD}, 125 \mathrm{MHz}\right)$ see supporting material; FABMS $m / z, 511[\mathrm{M}+\mathrm{H}]^{+}$.

20-Hydroxyecdysone 20,22-monoacetonide (9): White amorphous powder; IR $(\mathrm{KBr}) v_{\max } / \mathrm{cm}^{-1}: 3324,1661 ;{ }^{1} \mathrm{H} \mathrm{NMR}\left(\mathrm{CD}_{3} \mathrm{OD}\right.$, $400 \mathrm{MHz})$ and ${ }^{13} \mathrm{C} \mathrm{NMR}\left(\mathrm{CD}_{3} \mathrm{OD}, 100 \mathrm{MHz}\right)$ see supporting material. DARTMS $m / z, 521[\mathrm{M}+\mathrm{H}]^{+}$.

25-Acetoxy-20-hydroxyecdysone-3-O- $\beta$-D-glucopyranoside (11): White amorphous powder; IR (KBr) $v_{\max } / \mathrm{cm}^{-1}: 3371,1706,1646$; ${ }^{1} \mathrm{H} \mathrm{NMR}\left(\mathrm{CD}_{3} \mathrm{OD}, 400 \mathrm{MHz}\right)$ and ${ }^{13} \mathrm{C} \mathrm{NMR}\left(\mathrm{CD}_{3} \mathrm{OD}, 100 \mathrm{MHz}\right)$ see supporting material. ESIMS $707[\mathrm{M}+\mathrm{Na}]^{+}$.

\section{Evaluation of yeast $\alpha$-glucosidase activity}

$\alpha$-Glucosidase activity was evaluated using an adapted method of S. Xiao-Ping et al. ${ }^{20}$ A solution $(25 \mu \mathrm{L})$ of samples in DMSO- $\mathrm{H}_{2} \mathrm{O}$ 1:1 
was added to $150 \mu \mathrm{L}$ of phosphate buffer solution (PBS, $67 \mathrm{mmol} \mathrm{L}^{-1}$, $\mathrm{pH}$ 6.8) and incubated at $37^{\circ} \mathrm{C}$ for 10 min with $25 \mu \mathrm{L}$ of glutation (3 mmol L $\mathrm{m}^{-1}$ in PBS) and $25 \mu \mathrm{L}\left(0.2 \mathrm{U} \mathrm{mL}^{-1}\right)$ of $\alpha$-glucosidase type I (Sigma cat. G5003-100UN). The substrate solution $(25 \mu \mathrm{L}$, 23.2 mmol L-1 $p$-nitrophenyl- $\alpha$-D-glucopyranoside, Sigma N1377, in PBS) was then added and incubated with agitation for $15 \mathrm{~min}$ at $37{ }^{\circ} \mathrm{C}$. Reaction mixture was stopped with $50 \mu \mathrm{L}$ of $\mathrm{Na}_{2} \mathrm{CO}_{3}$ $\left(1 \mathrm{~mol} \mathrm{~L}^{-1}\right)$ and after $5 \mathrm{~min}$ of agitation the optical density was determined at $405 \mathrm{~nm}$. Acarbose and quercetin were used as positive controls. The inhibition percentage was calculated by the equation: Inhibition $(\%)=\left[\mathrm{OD}_{\text {control }}-\left(\mathrm{OD}_{\text {sample }}-\mathrm{OD}_{\text {background }}\right) / \mathrm{OD}_{\text {control }}\right] \times 100$.

Where $\mathrm{OD}_{\text {control }}, \mathrm{OD}_{\text {sample }}$ and $\mathrm{OD}_{\text {background }}$ are defined as the absorbance of $100 \%$ enzyme activity, test sample with enzyme, and test sample without enzyme, respectively. The concentration of an inhibitor required for inhibit the $50 \%$ of enzyme activity under the mentioned assay conditions is defined as $\mathrm{IC}_{50}$ value. All samples were tested in triplicated.

\section{Mammalian $\alpha$-glucosidase inhibition assay}

Mammalian $\alpha$-glucosidase was prepared following the modified method of Jo. ${ }^{21}$ Rat-intestinal acetone powder $(100 \mathrm{mg})$ was rehydrated with $4 \mathrm{~mL}$ of $67 \mathrm{mmol} \mathrm{L}^{-1}$ ice cold phosphate buffer $(\mathrm{pH}$ 6.8). After homogenization for 3 minutes at $4{ }^{\circ} \mathrm{C}$, the suspension was centrifuged $\left(13,400 \mathrm{rcf}, 4{ }^{\circ} \mathrm{C}, 30 \mathrm{~min}\right)$ and the resulting supernatant was used for the assay. A reaction mixture containing $150 \mu \mathrm{L}$ phosphate buffer (67 mM, pH 6.8), $25 \mu \mathrm{L}$ of $\alpha$-glucosidase and $25 \mu \mathrm{L}$ of sample (in DMSO 50\%) at different concentrations was pre-incubated for $10 \mathrm{~min}$ at $37{ }^{\circ} \mathrm{C}$, and $25 \mu \mathrm{L}$ of $23.2 \mathrm{mmol} \mathrm{L}-1$ p-nitrophenyl- $\alpha$-D-glucopyranoside were added. After $15 \mathrm{~min}$ incubation at $37{ }^{\circ} \mathrm{C}$, the reaction was stopped by adding $50 \mu \mathrm{L}$ of $\mathrm{Na}_{2} \mathrm{CO}_{3}\left(1 \mathrm{~mol} \mathrm{~L}^{-1}\right)$. Acarbose, and quercetin were used as a positive controls and DMSO 5\% as negative control. Enzyme activity was quantified by measuring the absorbance at $405 \mathrm{~nm}$ in a BioTek microplate reader Synergy HT. Experiments were done in triplicates. The percentage of enzyme inhibition by the sample was calculated by the following formula: Inhibition $(\%)=[(\mathrm{AC}-\mathrm{AS}) / \mathrm{AC})] \times$ 100 , where AC is the absorbance of the negative control and AS is the absorbance of the tested sample.

\section{Scavenging activity on free radical 2,2-diphenyl-1- picrylhydrazyl (DPPH)}

Free radical scavenging activity was measured using an adapted method of Mellors and Tappel, as previously reported. ${ }^{22}$

\section{Evaluation of the anti-inflammatory activity}

Animals: Male NIH mice weighing 25-30 g were maintained under standard laboratory, conditions in the animal house (temperature $22 \pm 4{ }^{\circ} \mathrm{C}$ ) with a $12 / 12 \mathrm{~h}$ light-dark cycle, according with the Mexican official norm MON-062-Z00-1999. They were fed laboratory diet and water ad libitum.

TPA-induced edema model. The TPA-induced ear edema assay in mice was performed as previously reported. ${ }^{23}$ (Table 3 ).

\section{Statistical analysis}

All data were represented as percentage mean \pm standard error of mean (SEM). The statistical analysis was done by means of Student's t-test, whereas analysis of variance ANOVA followed by Dunnett test were used to compare several groups with a control. $P$ values $\mathrm{p} \leq 0.05$ and $\mathrm{p} \leq 0.01$ were considered to be significant.

\section{RESULTS AND DISCUSSION}

The chemical study of the aerial parts of $S$. acuta afforded (Figure 1) a mixture of $\beta$-sitosterol (1) ${ }^{24}$ and stigmasterol (2), ${ }^{25}$ $13^{2}$-hydroxyphaeophytin a (3), ${ }^{26} \beta$-sitosteryl glucopyranoside (4), ${ }^{27}$ $p$-hydroxyphenethyl trans-ferulate (5), ${ }^{28}$ 20-hydroxyecdisone (6) ${ }^{28}$ 20-hydroxy-24-hydroxymethylecdysone (7), ${ }^{28}$ and uridine (10) ${ }^{29}$ S. rhombifolia yielded $\mathbf{1}$ and $\mathbf{2}$ as a mixture, $\mathbf{5}-\mathbf{7}$, inosine $(\mathbf{8}),{ }^{30}$ 20-hydroxyecdysone 20,22-monoacetonide (9), ${ }^{31}$ 25-acetoxy-20-hydroxyecdysone 3-O- $\beta$-D-glucopyranoside (11), ${ }^{13}$ and glycerol. ${ }^{32}$ Structures of the isolated products were determined by comparison of their physical constants and spectroscopic data with those reported in the literature. $13^{2}$-Hydroxyphaeophytin a (3), a degradation product of chlorophyll, and 20-hydroxyecdysone 20,22-monoacetonide (9) could be artefacts produced in the extraction of the plant or purification of the extracts, ${ }^{33}$ or generated by the plant metabolism. Thus, there is evidence of the presence of $\mathbf{3}$ at different stages of plant grown, ${ }^{34}$ and compound 9 has been isolated from plants with no acetone involved in their extraction and purification process..$^{28,31}$

Compound 6 had a molecular ion at $481 \mathrm{~m} / z[\mathrm{M}+\mathrm{H}]^{+}$in DARTMS, and in the IR spectrum showed absorption bands for hydroxy $\left(3347 \mathrm{~cm}^{-1}\right)$ and conjugated ketone groups $\left(1645 \mathrm{~cm}^{-1}\right)$. Its ${ }^{13} \mathrm{C} \mathrm{NMR}$ spectrum exhibited signals of twenty seven carbons: a carbonyl, two vynilic, six oxygenated, two quaternary, three methines, eight methylenes, and five methyls, and in the ${ }^{1} \mathrm{H}$ NMR spectrum the resonance of a vynilic proton at $\delta_{\mathrm{H}} 5.80$ which correlated with a carbonyl carbon $\left(\delta_{\mathrm{C}} 206.4\right)$ in the HMBC spectrum, suggested an ecdysone skeleton. The presence of the singlet resonances of five methyl groups together with those of the oxymethines $\mathrm{H}-2\left(\delta_{\mathrm{H}} 3.82\right.$, ddd, $J=12.0,4.0$, $2.8 \mathrm{~Hz}), \mathrm{H}-3\left(\delta_{\mathrm{H}} 3.93\right.$, brq, $\left.J=2.8 \mathrm{~Hz}\right)$, and $\mathrm{H}-22\left(\delta_{\mathrm{H}} 3.32, \mathrm{dd}, J=\right.$ $10.4,1.6 \mathrm{~Hz}$ ) allowed to identify compound $\mathbf{6}$ as 20-hydroxyecdysone. This compound has been isolated from several species of the genus Vitex, ${ }^{31}$ and of S. rhombifolia, ${ }^{13}$ and S. spinosa. ${ }^{28}$

Compound 7 showed a molecular ion at $511 \mathrm{~m} / \mathrm{z}[\mathrm{M}+\mathrm{H}]^{+}$in FABMS. Its ${ }^{1} \mathrm{H}$ NMR and ${ }^{13} \mathrm{C}$ NMR data were similar to those of compound $\mathbf{6}$, except for the presence of the resonances of a hydroxymethylene group $\left(\delta_{\mathrm{H}} 3.57\right.$, dd, $J=11.0,6.0 \mathrm{~Hz}$ and 3.50 , dd, $J=$ $\left.11.0,5.0 \mathrm{~Hz} ; \delta_{\mathrm{C}} 64.4\right)$, which was located at C-24 by the correlations of $\mathrm{H}-28$ with $\mathrm{C}-24$, and of $\mathrm{H}-24$ with $\mathrm{C}-23$ and $\mathrm{C}-25$ observed in the HMBC spectrum. Compound 7, identified as 20-hydroxy-24-hydroxymethylecdysone, has been isolated from S. spinosa. ${ }^{28}$

Compound 9, obtained as white amorphous powder, exhibited in the IR spectrum bands of hydroxy and conjugated ketone groups at 3424 and $1661 \mathrm{~cm}^{-1}$, respectively, and a molecular ion at $521 \mathrm{~m} / \mathrm{z}$ $[\mathrm{M}+\mathrm{H}]^{+}$in DARTMS. The NMR spectra of $\mathbf{9}$, as those of compounds $\mathbf{6}$ and 7, showed an ecdysteroid structure pattern, with the additional resonances of a ketal group: two methyl groups $\left(\delta_{\mathrm{H}} 1.41\right.$ and 1.33, $\delta_{\mathrm{C}} 26.9$, and 28.9) and a ketalic carbon $\left(\delta_{\mathrm{C}} 106.9\right)$. Compound 9 was identified as 20-hydroxyecdysone 20,22-monoacetonide, isolated previously of Vitex strickeri $i^{31}$ and S. spinosa. ${ }^{28}$

Compound 11 exhibited in the IR spectrum absorptions at 3371, 1706 , and $1646 \mathrm{~cm}^{-1}$ indicative of hydroxy, carbonyl, and conjugated ketone groups, and showed a quasi-molecular ion at $707 \mathrm{~m} / \mathrm{z}[\mathrm{M}+\mathrm{Na}]^{+}$ in ESIMS. The NMR spectra of $\mathbf{1 1}$ showed the characteristic features of an ecdysone with a sugar moiety whose anomeric proton resonated at $\delta_{\mathrm{H}} 4.34(\mathrm{~d}, J=8.0 \mathrm{~Hz})$. The HMBC correlation between this proton and $\mathrm{C}-3\left(\delta_{\mathrm{C}} 76.8\right)$ determined the localization of the sugar portion at this carbon. Additionally, the presence of the singlet signal of a methyl group at $\delta_{\mathrm{H}} 1.95$, and the resonances of a carbonyl carbon at $\delta_{\mathrm{C}} 172.7$ and a methyl at $\delta_{\mathrm{C}} 22.4$ indicated an acetyl group which was located at C-25 $\left(\delta_{\mathrm{C}} 83.9\right)$ by comparing its chemical shift with those reported in the literature. ${ }^{15}$ Compound 11 spectroscopic features were in agreement with 25-acetoxy-20-hydroxyecdysone 


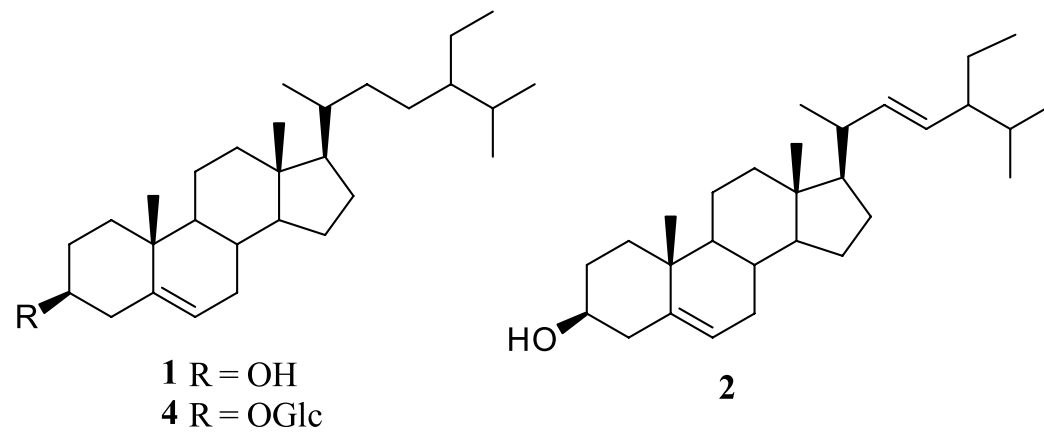<smiles>COc1cc(/C=C/C(C)=O)ccc1O</smiles>

$4 \mathrm{R}=$ OGlc<smiles>OCCc1ccc(O)cc1</smiles><smiles>O=c1[nH]cnc2c1ncn2C1OC(CO)C(O)C1O</smiles>

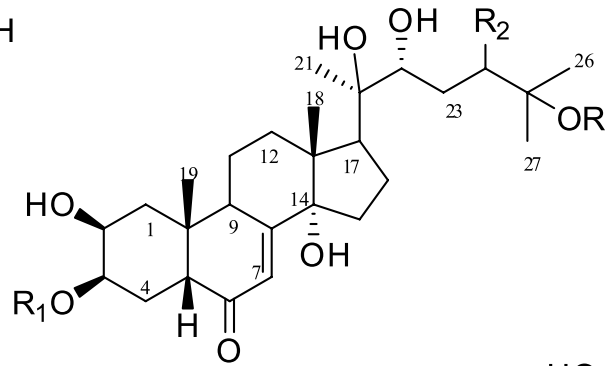

$$
\begin{aligned}
6 \mathrm{R} & =\mathrm{R}_{1}=\mathrm{R}_{2}=\mathrm{H} \\
7 \mathrm{R} & =\mathrm{R}_{1}=\mathrm{H}, \mathrm{R}_{2}=\mathrm{CH}_{2} \mathrm{OH} \\
11 \mathrm{R} & =\mathrm{Ac}, \mathrm{R}_{1}=\mathrm{Glc}, \mathrm{R}_{2}=\mathrm{H}
\end{aligned}
$$
PhyOOC'

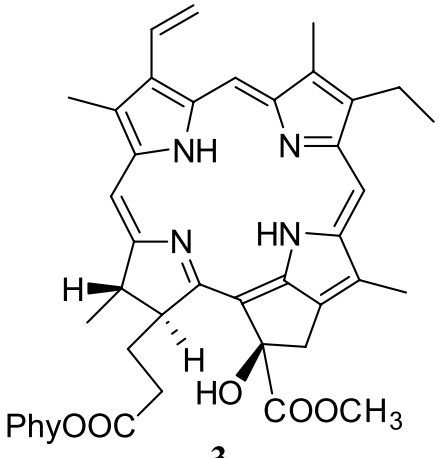

3

Figure 1. Compounds isolated from Sida acuta and Sida rhombifolia

3-O-B-D-glucopyranoside, previously isolated from S. rhombifolia. ${ }^{13}$

In previous reports, a slight reduction on blood glucose level in normal glycemic rats produced by the methanolic extract of leaves of S. acuta has been stablished, ${ }^{5}$ and a dose-dependent anti-hyperglicemic effect induced on diabetic rats by the methanolic and aqueous extracts of $S$. rhombifolia related to their antioxidant properties, was pointed out. ${ }^{12}$ Additionaly, the antioxidant effect of $S$. acuta and $S$. rhombifolia (L.) ssp. retusa extracts has been reported. ${ }^{2,35}$ However, there is no information of the effect of S. acuta and S. rhombifolia on $\alpha$-glucosidase, neither on the possible anti-hyperglicemic or antioxidant active compounds, therefore, the $\alpha$-glucosidase and antioxidant activities of extracts and isolates were determined. Moreover the anti-inflammatory effect of extracts and isolated compounds was also determined.

Because the substrate specificity of $\alpha$-glucosidase differs greatly depending on the source, and is well established that $\alpha$-glucosidase inhibitors show variable activities upon the origin of the enzyme, ${ }^{36}$ yeast (type 1) and mammalian (type 2) $\alpha$-glucosidases were used to determine the inhibitory activity of S. acuta and S. rhombifolia extracts and isolated metabolites (Table 1). Acarbose and quercetin were used as reference compounds since acarbose would be more active on mammalian $\alpha$-glucosidase ${ }^{37}$ while quercetin specificity would be higher for yeast $\alpha$-glucosidase. ${ }^{38}$

Results (Table 1) show that, in primary screening, using yeast $\alpha$-glucosidase the acetone extracts exhibited the highest inhibition of enzyme ( 82.45 and $88.52 \%$ ), while the methanol extracts were barely active and no activity was detected in hexane extracts. Among the isolated compounds $\beta$-sitosteryl glucopyranoside (4) and $p$-hydroxyphenethyl trans-ferulate (5) with 86.33 and $82.93 \%$ of enzyme inhibition, respectively, were the more actives. However, the activity of extracts and isolates decreased significantly in the mammalian $\alpha$-glucosidase test, indicating that the substrates affinity is higher for type 1 enzymes. In the concentration-response evaluation the acetone extracts showed concentration-dependent activities (Table 1S) with $\mathrm{IC}_{50}$ values of $8.49 \pm 0.66$ and $8.10 \pm 0.34 \mu \mathrm{g} \mathrm{mL} \mathrm{L}^{-1}$ for $S$. acuta and S. rhombifolia, respectively. $p$-Hydroxyphenethyl trans-ferulate (5) was the most active compound $\left(\mathrm{IC}_{50} 19.24 \pm 1.73 \mu \mathrm{mol} \mathrm{L}^{-1}\right)$, near to the reference compound quercetin $\left(\mathrm{IC}_{50} 15.61 \pm 1.68 \mu \mathrm{mol} \mathrm{L}^{-1}\right)$, followed by $\beta$-sitosteryl glucopyranoside $\left(4, \mathrm{IC}_{50} 32.70 \pm 1.35 \mu \mathrm{mol} \mathrm{L} \mathrm{L}^{-1}\right)$.

In primary screening of DPPH free radical scavenging activity only the acetone and methanol extracts of $S$. acuta and S. rhombifolia and compound 5 showed antioxidant properties (Table 2). In concentration-response evaluation (Table 2S) extracts showed rather moderated activities with $\mathrm{IC}_{50}$ of $220.54 \pm 6.47$ and $221.50 \pm 5.55 \mu \mathrm{g} \mathrm{mL}^{-1}$ for the acetone extracts of $S$. acuta and $S$. rhombifolia, respectively, which were the most actives. Compound $\mathbf{5}$, showed the highest activity with $\mathrm{IC}_{50}$ of $46.18 \pm 0.83 \mu \mathrm{mol} \mathrm{L}{ }^{-1}$, but was less active than $\alpha$-tocopherol $\left(\mathrm{IC}_{50} 31.74 \pm 1.04 \mu \mathrm{mol} \mathrm{L}{ }^{-1}\right)$, the reference compound.

The anti-inflammatory activity of extracts and compounds 4, 5-7, $\mathbf{9}$, and $\mathbf{1 1}$ was tested on the TPA model of induced acute inflammation. ${ }^{39}$ The effect on the edema (Table 3 ) of the acetone extracts $S$. acuta and S. rhombifolia was mild (46.36\% and $42.23 \%$, respectively) while the hexane and methanol extracts were not active. Among the tested compounds only compound $\mathbf{5}$ showed $48.49 \%$ of edema inhibition which was moderated compared with the reference compound indomethacin $(83.73 \%)$.

\section{CONCLUSIONS}

The chemical composition of S. acuta and S. rhombifolia collected in Mexico is in agreement with that reported for the genus Sida so far. On biological screening the acetone extracts of S.acuta 
Table 1. Effect of extracts and isolated compounds from S. acuta and S. rhombifolia on yeast and mammalian $\alpha$-glucosidase inhibition

\begin{tabular}{|c|c|c|c|}
\hline \multirow[t]{2}{*}{ Sample } & \multirow{2}{*}{$\begin{array}{c}\text { Mammalian } \\
\alpha \text {-glucosidase } \\
\text { Inhibition }(\%)^{\mathrm{b}, \mathrm{c}}\end{array}$} & \multicolumn{2}{|c|}{$\begin{array}{c}\text { Yeast } \\
\alpha \text {-glucosidase }\end{array}$} \\
\hline & & Inhibition $(\%)^{\mathrm{b}, \mathrm{c}}$ & $\mathrm{IC}_{50}(\mu \mathrm{mol} \mathrm{L}-1)$ \\
\hline Hexane extract of $S$. acuta $(\mathrm{SAH})$ & 0.37 & -21.57 & nd \\
\hline Hexane extract of S. rhombifolia (SRH) & 0.83 & -0.91 & nd \\
\hline Acetone extract of $S$. acuta (SAA) & 18.21 & 82.45 & $8.49 \pm 0.66^{\mathrm{d}}$ \\
\hline Acetone extract of S. rhombifolia (SRA) & 11.88 & 88.52 & $8.10 \pm 0.34^{\mathrm{d}}$ \\
\hline Methanol extract of S. acuta (SAM) & 8.28 & 24.02 & nd \\
\hline Methanol extract of S. rhombifolia (SRM) & 9.63 & 39.30 & nd \\
\hline Compound 1-2 & -0.69 & 32.00 & nd \\
\hline Compound 4 & -0.49 & 86.33 & $32.70 \pm 1.35$ \\
\hline Compound 5 & -0.36 & 82.93 & $19.24 \pm 1.73$ \\
\hline Compound 6 & -3.32 & -1.66 & nd \\
\hline Compound 7 & 2.14 & -4.09 & nd \\
\hline Compound 8 & 7.31 & -2.46 & nd \\
\hline Compound 9 & 2.40 & -1.33 & nd \\
\hline Compound $\mathbf{1 0}$ & 4.17 & -0.64 & nd \\
\hline Compound 11 & 10.32 & 0.95 & nd \\
\hline Acarbose & 55.94 & 10.6 & $7.26 \pm 0.34^{\mathrm{e}}$ \\
\hline Quercetin & 16.11 & 92.16 & $15.61 \pm 1.68$ \\
\hline
\end{tabular}

${ }^{\mathrm{a}} \mathrm{C}_{50}$ of extracts and tested metabolites on mammalian $\alpha$-glucosidase was not determined. ${ }^{\mathrm{b}}$ Concentrations of $100 \mu \mathrm{g} \mathrm{mL}^{-1}$ for extracts. ${ }^{\mathrm{C}} \mathrm{Concentrations}$ of 100 $\mu \mathrm{mol} \mathrm{L} \mathrm{L}^{-1}$ for pure compounds. ${ }^{\mathrm{d}} \mathrm{\mu g} \mathrm{mL}^{-1}$. ${ }^{\mathrm{e}} \mathrm{mmol} \mathrm{L}^{-1}$. The $\mathrm{IC}_{50}$ values were calculated from the dose response curve of seven concentrations of each tested sample in triplicated. All values are mean $\pm \mathrm{SD}(\mathrm{n}=3)$.

Table 2. DPPH free radical scavenging activity of extracts and isolated products from S. acuta and S. rhombifolia

\begin{tabular}{|c|c|c|}
\hline Sample & Inhibition of DPPH $(\%)^{\mathrm{a}, \mathrm{b}}$ & $\mathrm{IC}_{50}\left(\mu \mathrm{g} \mathrm{mL}^{-1}\right)$ \\
\hline SAH & 6.60 & nd \\
\hline SRH & 4.40 & nd \\
\hline SAA & 31.00 & $220.54 \pm 6.47$ \\
\hline SRA & 28.34 & $221.50 \pm 5.55$ \\
\hline SAM & 20.20 & $295.01 \pm 18.19$ \\
\hline SRM & 21.28 & $346.28 \pm 3.47$ \\
\hline Compound 1-2 & 1.23 & nd \\
\hline Compound 4 & 1.63 & nd \\
\hline Compound 5 & 61.02 & $46.18 \pm 0.83^{\mathrm{c}}$ \\
\hline Compound 6 & 2.30 & nd \\
\hline Compound 7 & 8.47 & nd \\
\hline Compound $\mathbf{8}$ & 6.16 & nd \\
\hline Compound 9 & -0.41 & nd \\
\hline Compound 11 & 1.18 & nd \\
\hline$\alpha$-tocopherol & 85.79 & $31.74 \pm 1.04^{\mathrm{c}}$ \\
\hline
\end{tabular}

${ }^{\mathrm{a} C}$ Concentrations of $100 \mu \mathrm{g} \mathrm{mL} \mathrm{g}^{-1}$ for extracts. ${ }^{\mathrm{b} C}$ Concentrations of $100 \mu \mathrm{mol} \mathrm{L}{ }^{-1}$ for pure compounds. ${ }^{c} \mu \mathrm{mol} \mathrm{L}{ }^{-1}$. The $\mathrm{IC}_{50}$ values were calculated from the dose response curve of seven concentrations of each tested sample in triplicated. All values are mean $\pm S D(n=3)$.

and S. rhombifolia behave similarly and were the most active in all evaluations. In yeast $\alpha$-glucosidase test, $p$-hydroxyphenethyl trans-ferulate (5) was the most active compound, followed by $\beta$-sitosteryl glucopyranoside (4). They were isolated from acetone and methanol extracts of both species. However, they may not be the only active compounds since the $\mathrm{IC}_{50}$ of the acetone extracts are lower than those of 5 and 4, or else there is a synergetic effect of the components of these extracts that accounts for the activity. In mammalian $\alpha$-glucosidase test, the activity was considerably lower than in yeast $\alpha$-glucosidase test, in both, and the increasing order of extracts activity was hexane, methanol, and acetone. This same order of activity was observed
Table 3. Effect of extracts and isolated products from S. acuta and S. rhombifolia on TPA-induced mouse edema

\begin{tabular}{|c|c|c|}
\hline Sample & Edema (mg) & Inhibition (\%) \\
\hline $\mathrm{SAH}^{\mathrm{a}}$ & $12.33 \pm 0.88$ & $20.22 *$ \\
\hline $\mathrm{SRH}^{\mathrm{a}}$ & $11.00 \pm 0.41$ & $28.26^{* *}$ \\
\hline $\mathrm{SAA}^{\mathrm{b}}$ & $7.37 \pm 0.76$ & $46.36^{* *}$ \\
\hline $\mathrm{SRA}^{\mathrm{b}}$ & $7.93 \pm 0.38$ & $42.23^{* *}$ \\
\hline $\mathrm{SAM}^{\mathrm{c}}$ & $12.80 \pm 0.92$ & 18.82 \\
\hline $\mathrm{SRM}^{\mathrm{c}}$ & $13.37 \pm 0.95$ & 15.22 \\
\hline Compound 4 & $12.73 \pm 0.30$ & 9.26 \\
\hline Compound $\mathbf{5}^{\mathrm{c}}$ & $7.40 \pm 2.16$ & 48.49 \\
\hline Compound $\mathbf{6}^{\mathrm{d}}$ & $14.33 \pm 0.78$ & 10.60 \\
\hline Compound $7^{\mathrm{d}}$ & $14.17 \pm 0.37$ & 11.64 \\
\hline Compound $\mathbf{9}^{\mathrm{d}}$ & $10.80 \pm 2.08$ & $32.64 * *$ \\
\hline Compound $\mathbf{1 1}^{\mathrm{d}}$ & $13.53 \pm 0.72$ & 15.59 \\
\hline Indomethacin ${ }^{e}$ & $1.99 \pm 0.69$ & $83.73 *$ \\
\hline
\end{tabular}

Dose: $1 \mathrm{mg} / \mathrm{ear}$ for extracts, $1 \mu \mathrm{mol} / \mathrm{ear}$ for pure compounds. Each value represents the mean of three animals \pm standard error. Control: achloroform $15.33 \pm 0.08$; ${ }^{b}$ acetone $13.73 \pm 0.64$, ${ }^{\mathrm{c}}$ methanol, $15.77 \pm 1.13$, ${ }^{\mathrm{d}}$ methanolacetone $1: 116.03 \pm 0.78$, eacetone, $13.53 \pm 1.04$. Results were analysed by the $t$ Student's test. ${ }^{*} \mathrm{p} \leq 0.05$. $* * \mathrm{p} \leq 0.01$.

in DPPH and TPA tests, indicating a possible relation between the $\alpha$-glucosidase inhibition and antioxidant and anti-inflammatory actions. Compound $\mathbf{5}$ was active in the three evaluations. This effect could be related to its phenolic character, since antioxidant phenolic compounds have been related to reduction of chronic inflammation, ${ }^{40}$ and their ability to inhibit digestive enzymes such as $\alpha$-glucosidase, $\alpha$-amylase, lipase and tripsine has been reported. ${ }^{41}$

\section{SUPPLEMENTARY MATERIAL}

${ }^{1} \mathrm{H}$ and ${ }^{13} \mathrm{C}$ NMR data of compounds 4-7, 9 and $11 ;{ }^{1} \mathrm{H},{ }^{13} \mathrm{C}$ NMR, 2D NMR spectra of compounds 4-7, 9 and 11; DARTMS of 
compounds 5, 6 and 9; concentration-response evaluation on yeast $\alpha$-glucosidase for acetone extracts and compounds $\mathbf{4}$ and $\mathbf{5}$; and concentration-response of DPPH free radical scavenging activity of acetone and methanol extracts and compound $\mathbf{5}$ are freely available at http://quimicanova.sbq.org.br in PDF.

\section{ACKNOWLEDGEMENTS}

We are indebted to Rubén Gaviño, Ma. de los Angeles Peña, Elizabeth Huerta, Isabel Chávez, Héctor Ríos, Beatriz Quiroz, Rocío Patiño, Javier Pérez, Carmen Garcia, and Luis Velasco for technical assistance.

\section{REFERENCES AND NOTES}

1. Mabberley, D. J.; The Plant Book, $2^{\text {nd }}$ ed., Cambridge University Press: Cambridge, 2000, p. 661; Fryxell, P. A.; Malvaceae of Mexico, In Systematic Botany Monographs, American Society of Plant Taxonomist, $1988,25,1-522$.

2. Konaté, K.; Sousa, A.; Coulibaly, A. Y.; Meda, N. T. R.; Kiendrebeogo, M.; Lamien-Meda, A.; Millogo-Rasolodimby, J.; Lamidi, M.; Nacoulma, O. G.; Pak. J. Biol. Sci. 2010, 13, 1092.

3. Banzouzi, J. T.; Prado, R.; Menan, H.; Valentin, A.; Roumestan, C.; Mallié, M.; Pelissier, Y.; Blacha, Y.; Phytomedicine 2004, 11, 338.

4. Dhalwal, K.; Shinde, V. M.; Mahadik, K. R.; J. Med. Plants Res. 2010 , 4, 1289; Sreedevi, C. D.; Latha, P. G.; Ancy P.; Suja, R. S.; Shyamal, S.; Shine, V. J.; Sini, S.; Anuja, G. I.; Rajasekharan, S.; J. Ethnopharmacol. 2009, 124, 171.

5. Arya, A.; Abdullah, M. A.; Haerian, B. S.; Mohd, M. A.; E-J. Chem. 2012, 9, 1196

6. Jang, D. S.; Park, E. J.; Kang, Y.-H.; Su, B.-N.; Hawthorne, M. E.; Vigo, J. S.; Graham, J. G.; Cabieses, F.; Fong, H. H. S.; Mehta, R. G.; Pezzuto, J. M.; Kinghorn, A. D.; Arch. Pharm. Res. 2003, 26, 585.

7. Khare, M.; Srivastava, S. K.; Singh, A. K.; J. Med. Aromat. Plant Sci. 2000, 24, 430; Ghosh, G.; Das, D.; Int. J. Pharm. Sci. Rev. Res. 2015 , 32, 209; Pooja, C.; Kuppast, I. J.; Virupaksha, J. H,; Ravi, M. C.; Int. J. Univers. Pharm. Bio Sci. 2015, 4, 36.

8. Aguilar, A.; Camacho, J. R.; Chin, S.; Jácquez, P.; López M. E.; Herbario Medicinal del Instituto Mexicano del Seguro Social. Información Etnobotánica, Instituto Mexicano del Seguro Social, 1994, México, p. 137-139; Martínez, M.; Las Plantas medicinales de México, Ed. Botas: México, 1959, pp. 414- 438; Bork, P. M.; Schmitz, M. L.; Weimann, C.; Kist, M.; Heinrich, M.; Phytomedicine 1996, 3, 263.

9. Malairajan, P.; Gopalakrishnan, G.; Narasimhan, S.; Veni K. J. K.; J. Ethnopharmacol. 2006, 106, 425.

10. Sarangi, R. R.; Mishra, U. S.; Panda, S. K.; Behera, S.; Int. Res. J. Pharm. 2011, 2, 157.

11. Chaves, O. S.; Gomes, R. A.; Tomaz, A. C. A.; Fernandes, M. G.; das Graças, M. L. J.; Agra, M. F.; Braga, V. A.; Souza, M. F. V.; Molecules 2013, 18, 2769.

12. Ghosh, G.; Subudhi, B. B.; Mishra, S. K.; Asian J. Chem. 2011, 23, 141.

13. Jadhav, A. N.; Pawar, R. S.; Avula, B.; Khan, I. A.; Chem. Biodivers. 2007, 4, 2225.

14. Rao, R. V. K.; Satyanarayama, T.; Rao, B. V. K.; Fitoterapia 1984, 55, 249.

15. Prakash, A.; Varma, R. K.; Ghosal, S.; Planta Medica 1981, 43, 384; Khatoon, S.; Srivastava, M.; Rawat, A. K. S.; Mehrotra, S.; J. Planar Chromatogr--Mod. TLC 2005, 105, 364.

16. Iswantini, D.; Darusman, L. K.; Hidayat, R.; J. Biol. Sci. 2009, 9, 504; Jindal, A.; Kumar, P.; Chitra, J.; Int. J. Drug Develop. Res. 2012, 4, 92.
17. Pradeep, T.; Haranath, C.; IJPRR 2014, 3, 23.

18. Lam, S.-H.; Chen, J.-M.; Kang, C.- J.; Chen, C.-H.; Lee, S.-S.; Phytochemistry 2008, 69, 1173; Phan, M. A. T.; Wang, J.; Tang, J.; Lee, Y. Z.; Ng, K.; LWT - Food Sci. Technol. 2013, 53, 492; Casirola, D. M.; Ferraris, R. P.; Metabol. Clin. Exp. 2006, 55, 832.

19. Dembinska-Kiec, A.; Mykkänen, O.; Kiec-Wilk, B.; Mykkänen, H.; Br. J. Nutr. 2008, 99, E-Supp. 1, ES109; Pickup, J. C.; Diabetes Care 2004, 27, 813; Lee, S. Y.; Mediani, A.; Nur Ashikin, A. H.; Azliana, A. B. S.; Abas, F.; Int. Food Res. J. 2014, 21, 165.

20. Xiao-Ping, Y.; Chun-Qing, S.; Ping, Y.; Ren-Gang, M.; Chin. J. Nat. Med. 2010, 8, 349.

21. Jo, S.-H.; Ka, E.-H.; Lee, H.-S.; Apostolidis, E.; Jang, H.-D.; Kwon, Y.-I.; Int. J. App. Res. Nat. Prod. 2010, 2, 52.

22. Chans, G. M.; Nieto-Camacho, A.; Ramírez-Apan T.; Hernández-Ortega, S.; Álvarez-Toledano, C.; Gómez, E.; Aust. J. Chem. 2016, 69, 279.

23. Arciniegas, A.; Pérez-Castorena, A. L.; Nieto-Camacho, A.; Villaseñor, J. L.; Romo de Vivar, A.; J. Mex. Chem. Soc. 2009, 53, 229.

24. Aldrich Library of ${ }^{13} \mathrm{C}$ and ${ }^{~} \mathrm{H}$ FT NMR Spectra, 1993, $1^{\text {st }}$ ed., vol. 3, 569 A.

25. Aldrich Library of ${ }^{13} \mathrm{C}$ and ${ }^{1} \mathrm{H}$ FT NMR Spectra, 1993, $1^{\text {st }}$ ed., vol. 3, 569 B.

26. Matsuo, A.; Ono, K.; Hamasaki, K.; Nozak, H.; Phytochemistry 1996, $42,427$.

27. Paulo, A.; Jimeno, M. L.; Gomes, E. T.; Houghton, P. J.; Phytochemistry 2000, 53, 417.

28. Darwish, F. M. M.; Reinecke, M. G. Phytochemistry 2003, 62, 1179.

29. Aldrich Library of ${ }^{13} \mathrm{C}$ and ${ }^{1} \mathrm{H}$ FT NMR Spectra, 1993, $1^{\text {st }}$ ed., vol. 3,371 B.

30. Aldrich Library of ${ }^{13} \mathrm{C}$ and ${ }^{1} \mathrm{H}$ FT NMR Spectra, 1993, $1^{\text {st }}$ ed., vol. 3,215 C.

31. Suksamrarn, A.; Sommechai, C.; Phytochemistry 1993, 32, 303; Zang, M.; Stout, M. J.; Kubo, I.; Phytochemistry 1992, 31, 247.

32. Aldrich Library of ${ }^{13} \mathrm{C}$ and ${ }^{1} \mathrm{H}$ FT NMR Spectra, 1993, $1^{\text {st }}$ ed., vol. 1, 283 C.

33. Schagerl, M.; Künzl, G.; Biologia Bratisl. 2007, 3, 270, Section Botany.

34. Piotrowska, A.; Bajgus, A.; Czerpak, R.; Kot, K.; J. Plant Growth Regul. 2010, 29, 53.

35. Dhalwal, K.; Deshpande, Y. S.; Purohit, A. P. J. Med. Food. 2007, 10, 683.

36. Kimura, A.; Lee, J.-H.; Lee, I.-S.; Lee, H.-S.; Park, K.-H.; Chiba, S.; Kim, D. Carbohydr. Res. 2004, 339, 1035.

37. Uddin, G.; Rauf, A.; Al-Othman, A. M.; Collina, S.; Arfan, M.; Ali, G.; Khan, I.; Fitoterapia, 2012, 83, 1648; Kim, K. Y.; Nam, K. A.; Kurihara, H.; Kim, S. M.; Phytochemistry 2008, 69, 2820.

38. Wang, H.; Du, Y.-J.; Song, H.-C.; Food Chem. 2010, 123, 6.

39. Rao, T. S.; Currie, J. L.; Shaffer, A. F.; Isakon, P. C.; Inflammation 1993, $17,724$.

40. Valenzuela-Barra, G.; Castro, C.; Figueroa, C.; Barriga, A.; Silva, X.; de las Heras, B.; Hortelano, S.; Delporte, C.; J. Ethnopharmacol. 2015, 168, 37; Laouini, S. E.; Segni, L.; Gherraf, N.; Ouahrani, M. R.; Mokni, S.; J. Fundam. Appl. Sci. 2013, 5, 171.

41. Marques, T. R.; Caetano, A. A.; Simão, A. A.; Castro, F. C. O.; Ramos, V. O.; Corrêa, A. D.; Rev. Bras. Farm. 2016, 26, 191; Zhang, B.; Deng, Z.; Ramdath, D. D.; Tang, Y.; Chen, P. X.; Liu, R.; Liu, Q.; Tsao, R.; Food Chem. 2015, 172, 862; Phoboo, S.; Pinto, M. S.; Barbosa, A. C. L.; Sarkar, D.; Bhowmik, P. C.; Jha, P. K.; Shetty, K.; Phytother. Res. 2013, 27, 227 